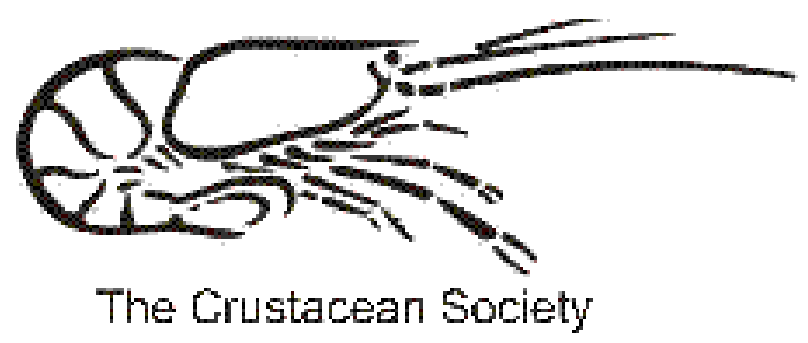

Ichthyoxenus fushanensis, New Species (Isopoda: Cymothoidae), Parasite of the Fresh-Water Fish Varicorhinus barbatulus from Northern Taiwan

Author(s): Min-Li Tsai and Chang-Feng Dai

Source: Journal of Crustacean Biology, Vol. 19, No. 4 (Nov., 1999), pp. 917-923

Published by: The Crustacean Society

Stable URL: http://www.jstor.org/stable/1549311

Accessed: 02/11/2009 05:07

Your use of the JSTOR archive indicates your acceptance of JSTOR's Terms and Conditions of Use, available at http://www.jstor.org/page/info/about/policies/terms.jsp. JSTOR's Terms and Conditions of Use provides, in part, that unless you have obtained prior permission, you may not download an entire issue of a journal or multiple copies of articles, and you may use content in the JSTOR archive only for your personal, non-commercial use.

Please contact the publisher regarding any further use of this work. Publisher contact information may be obtained at http://www.jstor.org/action/showPublisher?publisherCode=crustsoc.

Each copy of any part of a JSTOR transmission must contain the same copyright notice that appears on the screen or printed page of such transmission.

JSTOR is a not-for-profit service that helps scholars, researchers, and students discover, use, and build upon a wide range of content in a trusted digital archive. We use information technology and tools to increase productivity and facilitate new forms of scholarship. For more information about JSTOR, please contact support@jstor.org.

The Crustacean Society is collaborating with JSTOR to digitize, preserve and extend access to Journal of Crustacean Biology. 


\title{
ICHTHYOXENUS FUSHANENSIS, NEW SPECIES (ISOPODA: CYMOTHOIDAE), PARASITE OF THE FRESH-WATER FISH VARICORHINUS BARBATULUS FROM NORTHERN TAIWAN
}

\author{
Min-Li Tsai and Chang-Feng Dai
}

\begin{abstract}
A B S T R A C T
Ichthyoxenus fushanensis, new species, a flesh-burrowing parasite of Varicorhinus barbatulus, collected from a mountain stream in northern Taiwan, is described. It resembles the only congeneric species, I. formosanus, recorded in Taiwan, but can be distinguished from the latter by the narrower forehead, smooth posterior margin of pereionites, narrower pleotelson, shorter antennae 1 and 2 , and short carpus of pereiopod 1 . The two species also differ in the structure of the mouthparts, especially the number of terminal spines on the mandible and maxilliped. In addition, the two species occur in different habitats and on different hosts. Ichthyoxenus formosanus is found in the body cavity of the fresh-water carp, Carassius auratus, occurring in lakes or ponds. The morphological differences between free-living mancas and parasitic adults of Ichthyoxenus fushanensis are compared.
\end{abstract}

An undescribed cymothoid isopod of the genus Ichthyoxenus Herklots, 1870, was recently recovered from the fresh-water fish, Varicorhinus barbatulus (Pellegrin, 1908), in a mountain stream at Fushan Village, Wulai, Taipei County, in northern Taiwan. Ichthyoxenus is a genus of parasitic isopods that live on a variety of fresh-water and marine fishes. The distribution patterns and habitats of the species of Ichthyoxenus are highly diverse (Bruce, 1990). The taxonomic status of the genus Ichthyoxenus has long been questioned (reviewed in Bruce, 1990). The two central themes of these questions are: what are the taxonomic positions of Ichthyoxenus and Livoneca, and does Ichthyoxenus have a polyphyletic origin. Brusca (1981) suggested that Ichthyoxenus should be used for all Asiatic fresh-water flesh burrowers, with the implication that species in such different habitats (gill/buccal-attaching versus flesh burrowing) warrant different genera. Bruce (1990) confirmed that Ichthyoxenus and Livoneca are two separate genera. He recognized nine fresh-water and three marine species in Ichthyoxenus and speculated on the polyphyletic origin of the genus. The majority of species of Ichthyoxenus are from China and the Far East (Kuang and Chen, 1991). Members of this genus share the following characteristics: (1) body symmetrical, vaulted, strongly ovate, nearly circular in dorsal view; (2) cepahlon not deeply immersed in pereio- nite 1 ; (3) pleon narrow (less than 0.5 times as wide as pereion), pleonite 1 partly overlapped by pereionite 7 ; (4) antenna 2 shorter than antenna 1, bases set apart; and (5) pereiopods with short, rounded coxa, ischium to carpus flattened, widest distally, and dactylus short, flattened (Bruce, 1990). Little is known about the reproduction and the free-living mancas of species of Ichthyoxenus. In this paper, a new species of Ichthyoxenus is described and the free-living form is discussed. It is the first time that free-living mancas of the genus Ichthyoxenus have been described.

\section{MATERIALS AND Methods}

Specimens of Varicorhinus barbatulus were collected from Nanshih Hsi, a flowing mountain stream, and its tributaries at Fushan Village, Wulai, Taipei County in northern Taiwan (Fig. 1). Fish infested with isopods were easily detected by the presence of an external orifice at the base of the pectoral fins. Isopods were removed from the host with needles. Dissection of the isopods was conducted under a dissecting microscope and drawings were made with the aid of microscopic photography. Specimens examined in this study were deposited in the Institute of Oceanography, National Taiwan University (IONTU), and the National Museum of Natural Science, Taiwan (NMNS).

\section{SYSTEMATICS}

Family Cymothoidae

Ichthyoxenus fushanensis, new species Figs. 2, 3, 4

Material Examined.-Holotype: $\subsetneq(25.4 \mathrm{~mm})$, NMNS 2970-001, in body cavity of Varicorhinus barbatulus, 


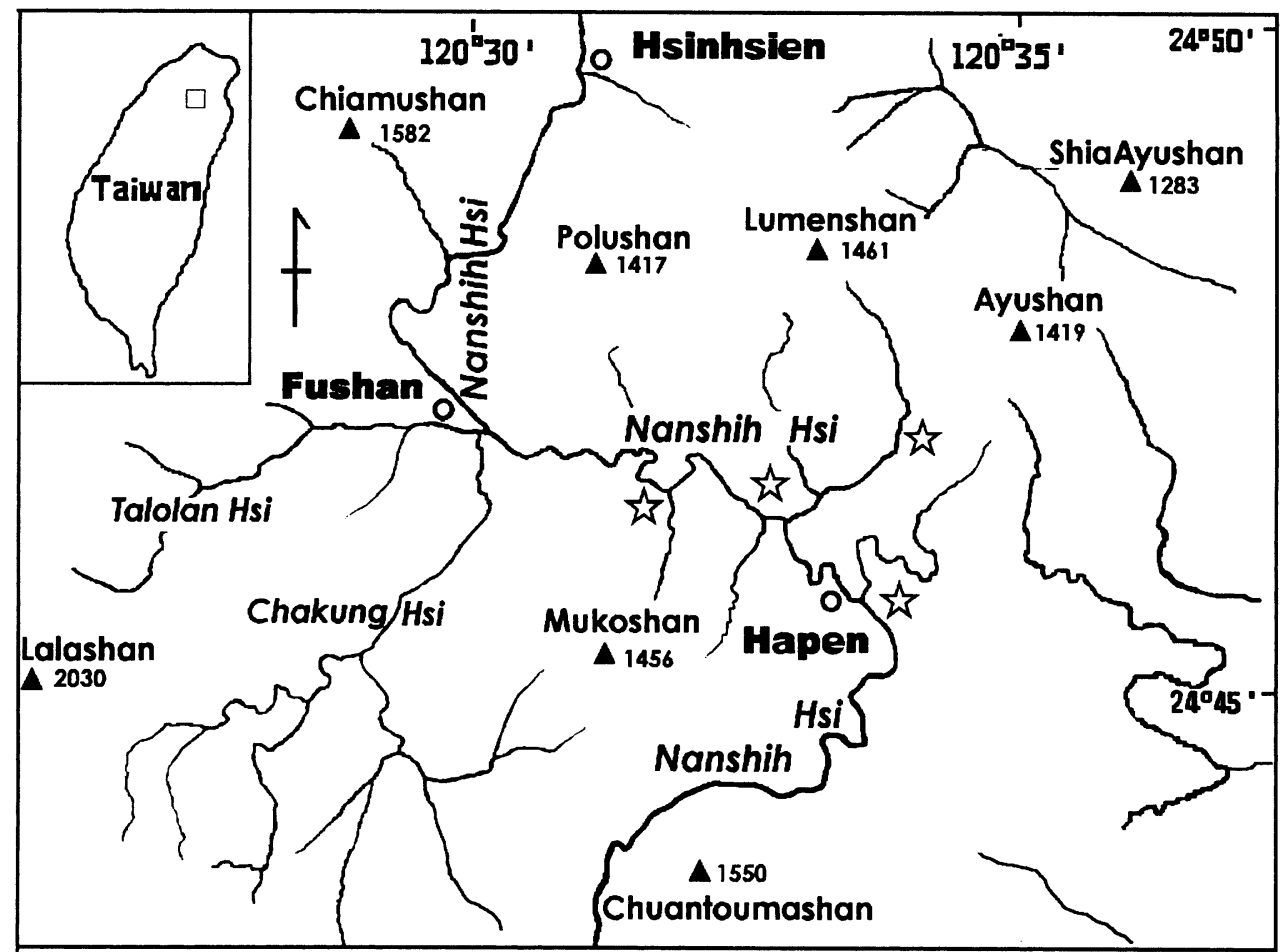

Fig. 1. Collection sites (§) of Ichthyoxenus fushanensis, new species.

collected at Nanshih Hsi, Fushan, Wulai, Taipei County, Taiwan, in November 1997, by M.-L. Tsai. Allotype: (11.8 mm), NMNS 2970-002; Paratype: Free-living manca $(3.5 \mathrm{~mm})$, NMNS 2970-003. Collecting data for allotype and paratype same as those of holotype.

Description.-Female. Body nearly bilaterally symmetrical (Fig. 2a), strongly ovate, surface ragged. Pereion subcircular in dorsal view, conspicuously expanded posterolaterally. Pereionite 1 longest, length 0.3 times width, anterior margin deeply excavated. Pereionites 3 and 4 widest, almost equal in width. Pereionites 5-7 gradually decreased posteriorly in width and length, with lateral parts strongly produced posteriorly on both sides. Posterior margin of pereionites smooth and rounded without triangular excavation in middle.

Cephalon small, frontal margin of rostrum bent downward and slightly rounded (Fig. 2b). Forehead narrow, fine transverse groove in front of eyes. Eyes black, oblong, located obliquely on anterolateral surface of head, shortest distance between 2 eyes 1.3 times longest axis of eye. Both antennae 1 and 2 reduced, 7-segmented (Fig. 2c). Antenna 1 reaching slightly beyond middle of eye. Antenna 2 longer than antenna 1 , reaching be- yond posterior margin of eye. Mandibular palp article 3 with 2 setae (Fig. 2d). Maxilla 1 narrow and platelike, with 3 terminal spines at tip (Fig. 2e). Maxilla 2 with 3 terminal spines curved outward (Fig. 2f). Maxilliped lobate, well developed, especially in ovigerous individuals, with 2 recurved terminal spines (Fig. 2g).

Pereiopods 1-3 shorter than 5-7. Coxae rudimentary, propodi short and stout, and dactyli flat. Pereiopod 1 carpus short and as wide as propodus (Fig. 2h). Pereiopod 7 basis with convex posterior margin; ischium almost as long as basis; merus and carpus flattened and posteriorly expanded; propodus short, stout and convex on anterior margin (Fig. 2i).

Pleon narrow, 6-segmented, pleonites 1-5 almost equal in width. Pleotelson not wider than other pleonites (Fig. 2a). Pleopods lamellar, peduncles and rami without lamellar lobes; endopod lobes of pleopods 3-5 weakly developed. Pleopod 1 largest and pleopod 5 smallest. Uropod biramous reaching slightly beyond posterior margin of pleotelson. Penes lobes reduced in length, in comparison with those found in male (Fig. 1j). Remnants of appendix masculina absent. 


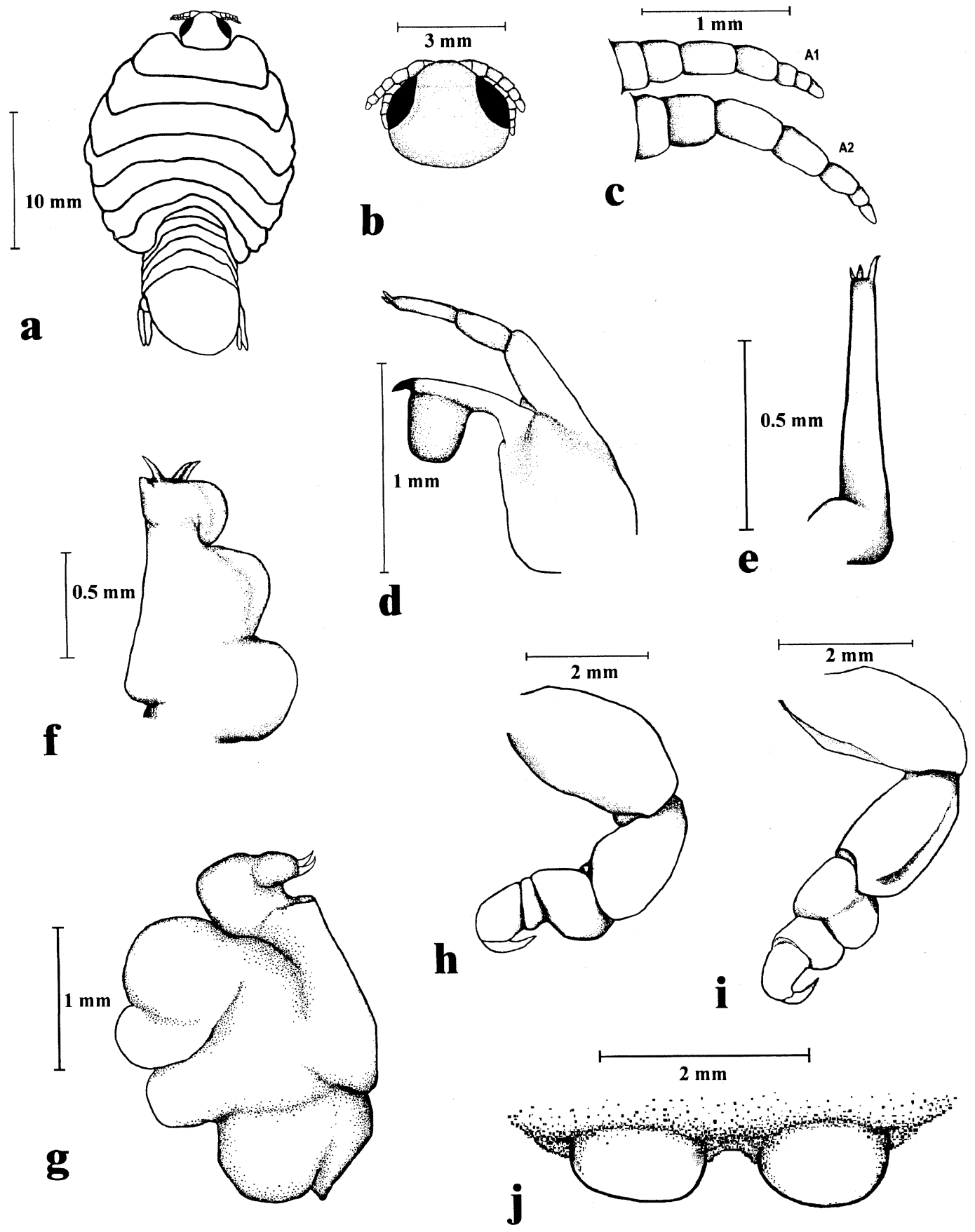

Fig. 2. Ichthyoxenus fushanensis, new species, holotype, female. a, dorsal view; b, head; c, antennae 1 and 2; d, mandible; e, maxilla 1 ; f, maxilla 2 ; g, maxilliped; $h$, pereiopod 1 ; i, pereiopod 7 ; , penes lobes.

Male. Male much smaller in body size $(11.8 \mathrm{~mm})$ and more oblong in body shape than female (Fig. 3a). Black dots scattered over whole body surface. Maxilliped simpler than that of female (Fig. 3b), and less devel- oped as in mancas. Penes lobes longer (Fig. $3 \mathrm{c})$ than those of females. Endopodite of pleopod 2 with appendix masculina (Fig. 3d). Uropods relatively slender compared to those of female. 

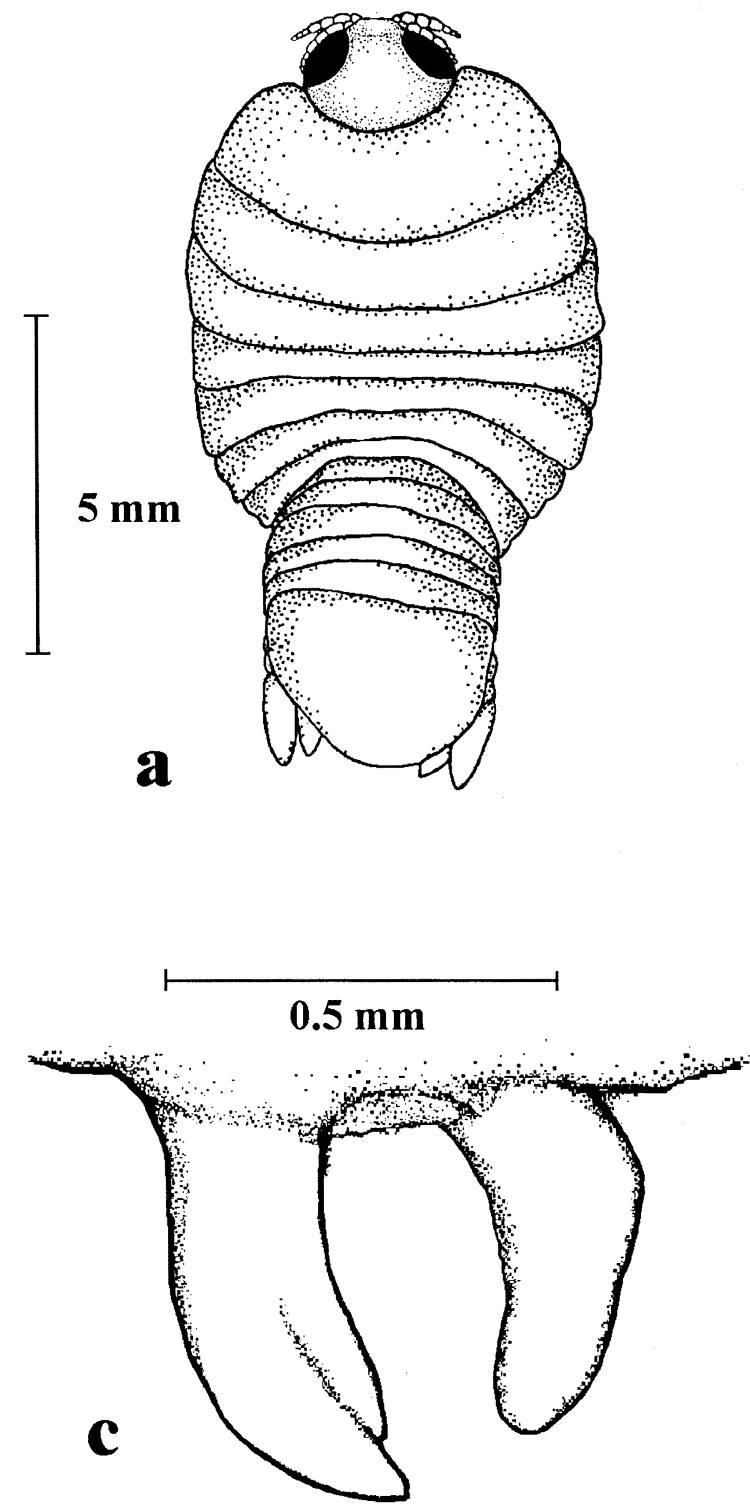
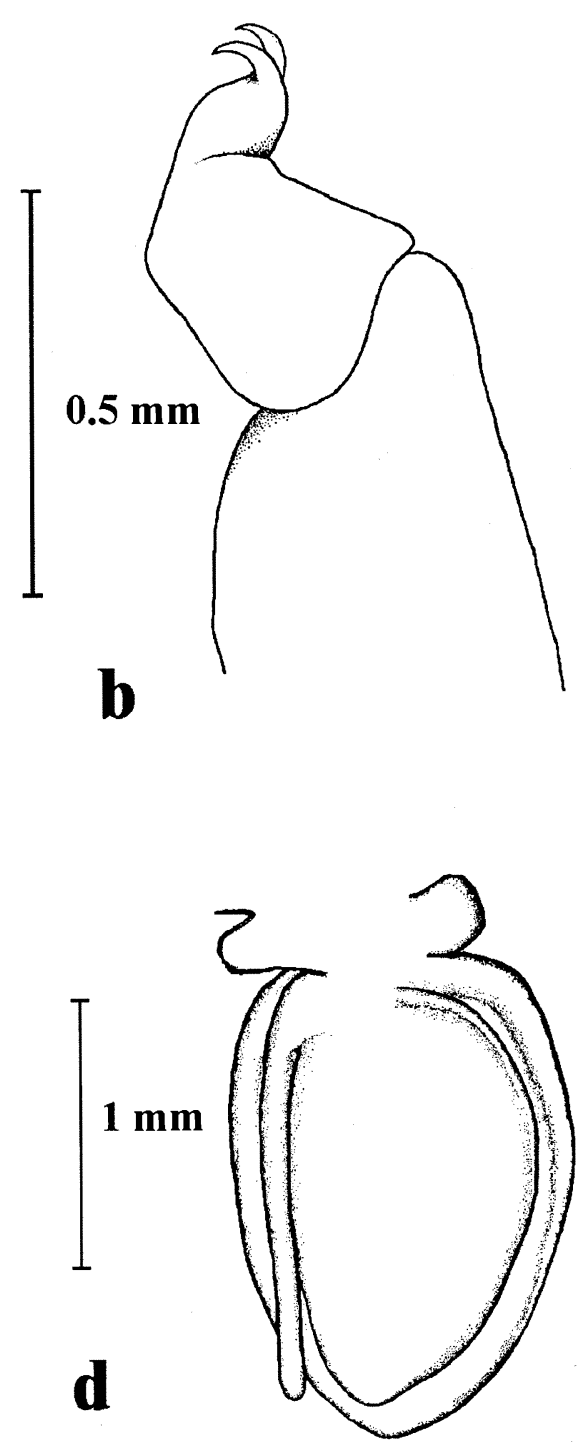

Fig. 3. Ichthyoxenus fushanensis, new species, allotype, male. a, dorsal view; b, maxilliped; c, penes lobes; d, pleopod 2.

Free-living mancas. Dorsal surface dark, with intense black dots. Body (Fig. 4a) elongate, with relatively longer and wider uropods and pleotelson than those of adult. Antenna 1 with 8 articles, reaching to pereionite 1 . Antenna 2 with 9 articles, reaching to pereionite 2 (Fig. 4b). Both antennae with 3 terminal setae on distal article and unequal number of setae scattered on surface in each article. Maxilliped similar to that of male but smaller (Fig. 4c). Pereionite 7 less developed and pereiopod 7 absent. Pleopods almost cir- cular in appearance and equal in size; exopod with 14-16 setae on lateral and distal margins (Fig. 4d). Pleotelson and uropod covered with row of marginal setae, and each seta highly plumose with dense fine setules on both margins (Fig. 4e).

Etymology.-The species name is derived from the locality where the specimens were collected.

Color-Color of living females was creamy white with minute black dots scattered over 


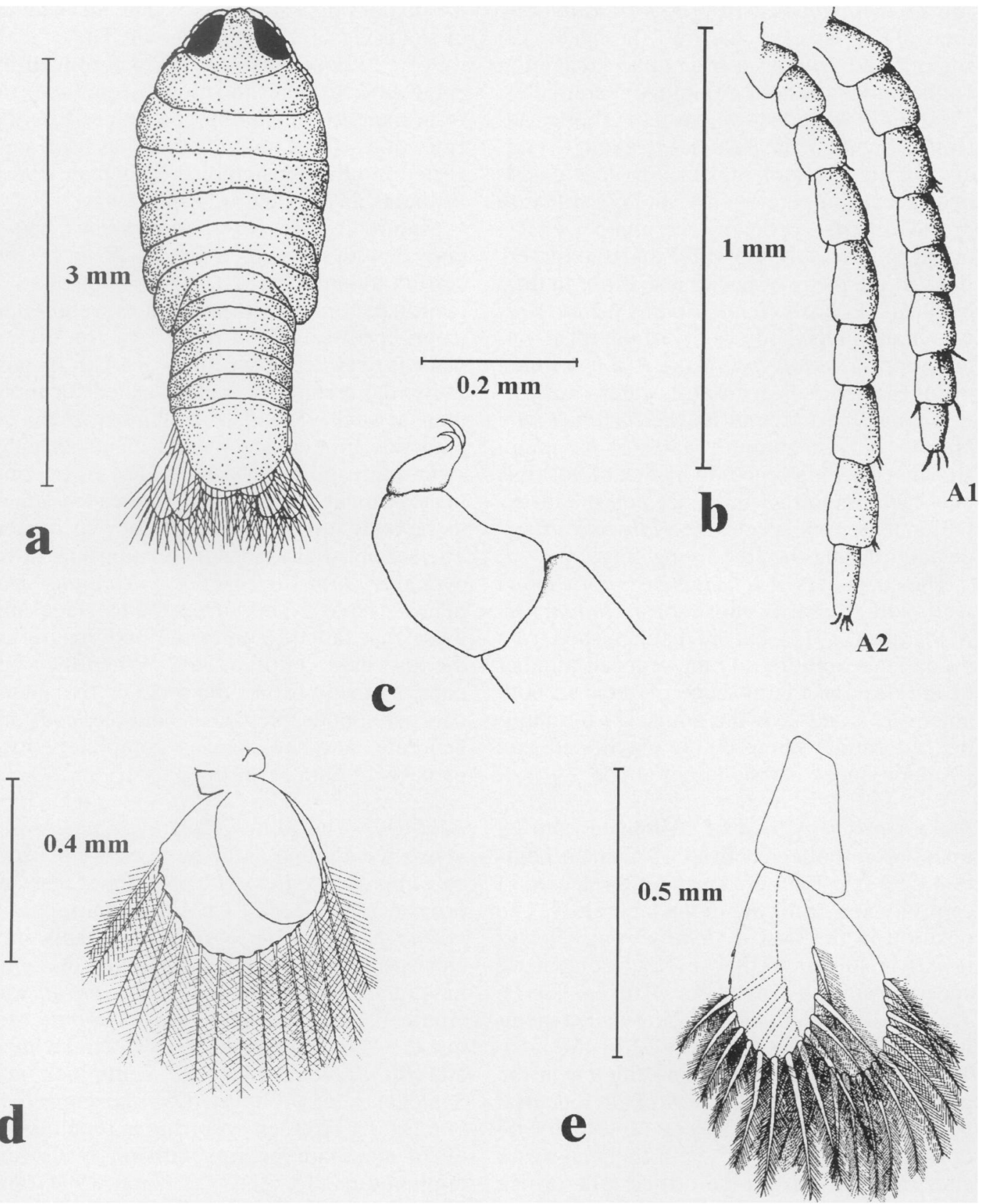

Fig. 4. Ichthyoxenus fushanensis, new species, paratype, free-living manca. a, dorsal view; b, antennae 1 and 2; c, maxilliped; d, pleopod 5; e, uropod.

the margin of head and body surface. An upside down V-shaped brown band appeared on the middorsal surface of the pereion in ovigerous females. Males had more black dots scattered evenly on the body surface. The color of free-living mancas is darker than that of males and females.
Remarks.-This species is closest to and shares many morphological characters with Ichthyoxenus formosanus Harada, 1930. Ichthyoxenus formosanus was recorded from Lake Candidius in central Taiwan, but absent from our collection. According to the descriptions by Harada (1930), I. fushanensis 
can be distinguished from I. formosanus by the: (1) relatively narrow forehead, (2) smooth and without a triangular excavation on the middle posterior margin of pereionites, (3) slightly extruded eye base, (4) shorter antennae 1 and 2 with 7 articles in adult, (5) relatively narrower pleotelson, (6) less developed carpus in pereiopod 1, and (7) structure of mouthparts, especially the number of terminal spines on the mandible and maxilliped. In addition, the two species also differ in their habitats and hosts. Ichthyoxenus formosanus was found in the body cavity of the fresh-water carp, Carassius auratus (L.), a fish found in lakes or ponds with still water, while $I$. fushanensis was found in Varicorhinus barbatulus only in running water of mountain streams. The differences in habitat of host fish may have important influences on the distribution pattern of species of Ichthyoxenus, especially during the free-living stage.

The characters of I. fushanensis correspond well with most of those of I. japonensis Richardson (1913), but are distinguished from the latter mainly by (1) the reduced number of articles and the absence of setae in both antennae 1 and 2 of the adult, (2) the number of terminal spines on the maxilliped, and (3) the reduced carpus in pereiopod 1.

Life History.-A total of 23 females and 28 males were collected from 28 fish. In addition, 252 free-living mancas were released in captivity and collected in the laboratory. The position in the host of Ichthyoxenus fushanensis is similar to that in other congeneric species of flesh-burrowers (Brusca, 1981). The parasites are found in a thin-walled membranous sac in the body cavity of the host. The opening of the sac is an orifice near the posterior and ventral region of the pectoral fin of the host fish. The isopods usually lie upside down in the sac, with their posterior ends oriented toward the orifice. The orifice opens directly to the outer environment, and provides a channel for gas exchange, excretion for the occupants, and release of mancas.

The parasites were usually found in pairs (male and female). Some were found as single males, but never as single females. When present in pairs, females were larger than males. The reduced penes in females suggest that sex reversal may be common in the species. Brusca (1981) suggested that sex reversal is common in cymothoids, at least super- ficially, during a single molt. The mechanism of sex reversal is still unknown. The sexuality of $I$. fushanensis is likely determined by epigenetic sex determination. Sexual reversal from male to female may be induced by the entry of a second individual, as has been suggested in other cymothoids (Bowman, 1960; Williams and Williams, 1980, 1985).

Mature females of I. fushanensis had a body length varying from $18-26 \mathrm{~mm}$, and carried about 275-820 eggs or embryos in their marsupia. Brooding females were found from April-July. The release of free-living mancas occurred from June-October. In captivity, the release of mancas lasted for more than a week. The dense plumose setae on pleopods, uropod, and pleotelson enhance the swimming ability of mancas. The free-living mancas are good swimmers and readily attach to the body surface of any fish they encounter. They establish the parasitic relationship, however, only with Varicorhinus barbatulus. The mancas have a short free-living stage and those that failed to enter the body cavity of the host died within a week. When they become parasitic forms, the setae on the antennae, pereiopods, pleotelson, and pleopods degenerate, and the mancas completely lose their swimming ability.

Ecology.-The adults of Ichthyoxenus fushanensis were found in the body cavity of Varicorhinus barbatulus. The prevalence was approximately $12.5 \%$. The infestation of $I$. fushanensis on $V$. barbatulus was likely species-specific. Other fishes inhabiting the same habitat, such as Acrossocheilus paradoxus Gunther, Zacco barbata Regan, Cobitis taenia L., Crossostoma lacustre Steindachner, and Rhinigobius brunneus Temminck and Schlegel, were not infested. Varicorhinus barbatulus is a browser, occurring in running water of mountain streams with relatively low temperature $\left(15-21^{\circ} \mathrm{C}\right)$ (Chang, 1994) and high dissolved oxygen $(7.5-9.6 \mathrm{mg} / \mathrm{l})$. Although $V$. barbatulus is widely distributed and may be found in most of the mountain streams throughout Taiwan, only those in the upstream of Nanshi Hsi at an altitude ranging from 520-1,230 m were infested with $I$. fushanensis. The dispersal of I. fushanensis may be restricted by special environmental conditions.

All of the infested fish were shorter than 14 $\mathrm{cm}$ in body length. Uninfested adult fish may 
reach about $23 \mathrm{~cm}$. Infestation with Ichthyoxenus fushanensis may reduce the growth rate or may have a lethal effect on the host fish.

\section{ACKNOWLEDGEMENTS}

We thank Drs. Chang-tai Shih and Ju-shey Ho for their critical comments on the manuscript. This study was partly supported by grants from the National Science Council, R.O.C. (NSC 87-2311-B-002A-001-B222 and NSC 88-2811-B002-0068).

\section{LiTERATURE CITED}

$\rightarrow$ Bowman, T. E. 1960. Description and notes on the biology of Lironeca puhi, n. sp. (Isopoda: Cymothoidae) parasite of the Hawaiian moray eel, Gymnothorax eurostus (Abbott).-Crustaceana 1: 84-91.

Bruce, N. L. 1990. The genera Catoessa, Elthusa, Enispas, Ichthyoxenus, Idusa, Livoneca and Norileca n. gen. (Isopoda, Cymothoidae), crustacean parasites of marine fishes, with descriptions of eastern Australian species.-Records of the Australian Museum 42: 247-300.

Brusca, R. C. 1981. A monograph on the Isopoda Cymothoidae (Crustacea) of the eastern Pacific.-Zoological Journal of Linnean Society 73: 117-199.

Chang, S. H. 1994. The population ecology of Varicorhinus barbatulus in Ha-Pen creek.-Master's the- sis, National Taiwan University. Pp. 1-112. [In Chinese, with English abstract.]

Harada, I. 1930. Studies on the freshwater fauna of Formosa. III. Note on a new Ichthyoxenus parasitic on Carassius duratus L.-Journal of the Society of Tropical Agriculture, Taiwan 2: 264-269.

Kuang, P., and J. Chen. 1991. Economic fauna of China: parasitic Crustacea of freshwater fishes.-Science Press, Beijing, China. Pp. 1-203.

Richardson, H. 1913. The isopod genus Ichthyoxenus Herklots, with description of a new species from Japan.-Proceedings of the United States National Museum 45: 559-562.

Williams, Jr., E. H., and L. B. Williams. 1980. Four new species of Renocila (Isopoda: Cymothoidae), the first reported from the New World.-Proceedings of the Biological Society of Washington 93: 573-592.

, and 1985. Cuna insularis n. gen. and n. sp. (Isopoda: Cymothoidae) from the gill chamber of the sergeant major, Abudefduf saxatilis (Linnaeus) (Osteichthyes) in the West Indies.-Journal of Parasitology 71: 209-214.

RECEIVED: 15 October 1998.

ACCEPTED: 19 January 1999.

Address: Institute of Oceanography, National Taiwan University, Taipei, Taiwan, Republic of China. 